\title{
Ieromin A. MODELING OF PARAMETERS OF PIPELINES OF CENTRAL WATER HEATING SYSTEM AND THERMAL INSULATION OF THE FACADE OF UKRAINIAN BUILDINGS AND FACILITIES FOR DIFFERENT CLIMATIC CONDITIONS
}

Об’єктом дослідження є конструктивні параметри та матеріал виконання елементів комплексної термомодернізацї будівлі чи споруд, а саме системи центрального водяного опалення та фасадної теплоізолящї, з урахуванням дї кліматичних зон, в яких експлуатуються зазначені об'єкти. Одними з найбільш проблемних місиь є недостатнья вивченість та відсутність обгрунтування ефективних конструктивних параметрів та матеріалу виконання трубопроводів системи щентрального водяного опалення та фасадної теплоізоляції. Це необхідно для суттєвого зменшення енергоспоживання існуючих будівель і споруд українсъкого житлового фонду. В ході дослідження використовувся комплексний підхід до вирішення поставлених завдань, включаючи економічний і статистичний аналіз, аналіз світового досвіду та синтез результатів і ретроспективи, історико-еволючійний та логічний підхід. Також використовувались теорія систем i системний аналіз для ідентифікачї стратегічних перспектив значного скорочення енергоспоживання існуючих українських будівель і споруд. У перспективі передбачається дисеміначія отриманих результатів на зарубіжні будівлі і споруди, що мають аналогічні пробеми з енергоефективності, у тому числі з урахуванням кліматичних зон. Обгрунтувано ефективні конструктивні параметри та матеріал виконання трубопроводів системи центрального водяного опалення для суттєвого зменшення енергоспоживання існуючих будівель і споруд українського житлового фонду. Визначено мінімальну товщину шару фасадної теплоізоляції, що становить 50 мм, для досліджуваного температурного режиму $і$ умов експлуатації, а також для характеристик використовуваних матеріалів, геометрії трубопроводів і фасадної теплоізоляцї для першої температурної зони. Отримана оптимальна товщина шару фасадної теплоізоляції, шо становить 100 мм, та приводить до 100 \%-го захисту від замерзання трубопроводів навіть при повній зупинці руху теплоносія протягом більше, ніж 24 години після припинення руху теплоносія. Розроблені інноваційні проектні та конструктивно-технологічні рішення приводять до значного зменшення енергоспоживання існуючих будівель $і$ споруд житлового фонду, що експлуатується понад 30 років $і$ які розміщені у різних кліматичних зонах, і сприяють підтриманню комфортних умов для життєдіяльності.

ключові слова: термомодернізація будівель і споруд, фасадна теплоізоляція, система центрального водяного опалення.

\section{Introduction}

In works [1,2] the range of innovative technical solutions for thermomodernization (thermal sanation) of structures and buildings was defined as part of the system of central water heating and facade thermal insulation. On the basis of experimental-numerical and computational studies, the rationale for their effectiveness was compared with the technical solutions that were developed.

In this direction, the actual further development is the modeling of constructive and technological parameters of new transit pipelines of the central water heating system and equivalent thermal insulation of the facade for different climatic conditions. These modeling results expand the geographic boundaries of the application of the developed technical solutions that emphasize the relevance of the research direction of thermomodernization and its export orientation.

\section{The object of research and its technological audit}

The object of research is the design parameters and material for the execution of the elements of the complex thermomodernization of a building or structures, namely the system of central water heating and facade thermal insulation, taking into account the effect of climatic zones in which these facilities are operated.

It was noted in works [1, 2] that significant heat consumption during heating of any buildings and structures is caused by increased heat losses through external enclosing structures of buildings or structures. Especially it concerns the building structures of old (in particular, before 1991) buildings through which heat is lost several times more than in modern buildings.

Another problematic situation is associated with low energy efficiency of old heating systems, which are built on 
a single-pipe central heating system. With such heating system, even completely insulating the house or building from the outside, in practice it is impossible to save heat energy and create comfortable conditions for living or working.

Therefore, one of the main methods of significantly reducing the material and financial costs of heating existing buildings and structures is a significant reduction in the amount of consumed heat energy. At the same time, the point application of certain energy-efficient measures gives an appropriate «point» result.

This is precisely the essence of the thermomodernization of buildings and structures, in order to significantly reduce heat consumption. Therefore, it is promising to justify the effective design parameters and material for the execution of pipelines for the central water heating system and facade insulation for a significant reduction in the energy consumption of existing buildings and structures of the Ukrainian housing stock.

Particular importance of the research topic is acquired due to the fact that Ukrainian (and not only) buildings and structures are located in different climatic zones. In particular, in such conditions, the investigated objects are located in the Russian Federation, Kazakhstan, the Czech Republic, Slovakia, Poland and the like. Therefore, the technical solutions proposed in this paper can be extended to these countries, in particular, Central and Eastern Europe.

\section{The aim and objectives of research}

The aim of research is modeling based on the developed innovative technical solutions for thermomodernization of the effective parameters of pipelines of the central water heating system and the thermal insulation of the facade for different climatic conditions. This is aimed at the final reduction of energy consumption of existing buildings and structures of both residential and non-residential facilities.

To achieve this aim, it is necessary to perform the following tasks:

1. To substantiate the effective design parameters and material for the execution of pipelines of the central water heating system to significantly reduce the energy consumption of existing buildings and structures of the Ukrainian housing stock.

2. To substantiate the effective design parameters and material for the execution of elements of facade thermal insulation.

3. To carry out modeling of effective parameters of pipelines of the central water heating system and thermal insulation of the facade for different climatic conditions.

\section{Research of existing solutions of the problem}

Normative and technical documentation on the investigated problem is represented by the corresponding GOST [3] and the State Building Regulations (DBN) [4]. According to these sources, minimum requirements to heat engineering indicators of structures of the thermal insulation of buildings and to energy characteristics of buildings or their separate parts are established. These indicators are determined on the basis of economically justified level of energy efficiency of the building. At the same time, the anticipated life cycle of the building is taken into account, provided that the household's human needs are met and optimal microclimatic conditions for its stay and/or living in the premises of such building are created.

Separate aspects of the investigated problem of thermomodernization of buildings and structures are studied in a number of works of foreign researchers. Thus, for example, in [5], a polyoptimal method is used to determine schemes for thermomodernization of buildings based on the theory of fuzzy sets in order to minimize the total cost of thermomodernization and simultaneously maximize the resulting energy effect in the form of reducing the cost of thermal energy. In work [6] it is noted the importance of solving the problem of thermomodernization due to the existence of a significant number of prefabricated, with bearing walls, apartment buildings. After all, they were built in the 50's, 60's and 70's of the last century in the countries of Central and Eastern Europe. Accordingly, new energy efficiency standards in force in EU countries should be taken into account.

The investigated problem is extremely important for the countries of the former social camp, with which Ukraine borders. The test methods used and the results of estimating the data necessary for predicting the consumption of thermal energy in a typical house of the average statistical family in Poland are obtained in [7]. Aspects of thermomodernization of buildings and evaluation of its influence on the created internal microclimate of these buildings are investigated in [8].

The issue of preserving the historical heritage of buildings that make up the national heritage, through the implementation of their thermomodernization, is highlighted in [9]. The directions of increasing energy efficiency as a result of thermomodernization of existing buildings are investigated in [10]. Optimum energy requirements and their influence on possible options for thermomodernization of a typical residential house are described in [11].

The relationship between the implementation of energyefficient thermomodernization in terms of environmental sustainability in the future is investigated in [12]. Numerical analysis of the behavior of the district heating system in dynamics is carried out in [13] with the help of a mathematical model, adequately described a simplified system of district heating with three end users and a $9 \mathrm{~km}$ pipeline network.

The system of thermomodernization of buildings and structures should be built and analyzed on the basis of an integrated approach, in particular, using structural and parametric modeling. This makes it possible, according to [14], to model the relationships between the structural elements of the investigated system, in particular, the thermomodernization system.

Aspects of the study of facade thermal insulation of buildings and structures are devoted to a number of works. The variant of using another insulating material that allows diffusive air in the insulating structure and contributes to the reduction of heat consumption is proposed by the authors [15]. Investigation of the current state of thermal insulation of walls without expandable poly styrene (EPS) and existing windows of buildings on a concrete example of Alipasino polje, in Sarajevo, Bosnia and Herzegovina, is covered in [16].

The automated approach to the analysis of energy efficiency of building facades that allows to obtain thermographic 3D-models and their corresponding orthoimages 
are given in the study [17]. In [18] it is noted that the most acceptable energy-efficient facade for all climatic zones is the external thermal insulation system in combination with any type of insulation. In particular, it can be a ventilated facade in combination with impact resistant insulation materials.

The study [19] proposes a methodological basis for assessing the external thermal insulation composite system in terms of ensuring high thermal stability and speed of installation. In work [20] it is noted the efficiency of using the double facade in buildings of various types in terms of reducing the consumption of thermal energy and providing thermal comfort. To reduce the urban greenhouse effect and improve the thermal characteristics of buildings, including for their modernization, it is proposed in [21] to widely use the so-called «green» facades. And in [22], energy-efficient sensory heating systems based on radiating panels are being investigated, suitable for houses with low energy consumption.

The model of switchable insulating so-called U-element based on a double-glass unit with a translucent insulating panel installed inside, to investigate the effect of various thermal properties on the $\mathrm{U}$-value, is considered by the authors [23]. In [24], the physical and mechanical properties of natural heat-insulating composites are analyzed, in particular, on the basis of fiber hemp, which are characterized by low density and porous structure, and are also suitable for the production of heat-insulating facades.

The method of selection and calculation of design and technological parameters of an ultrasonic low-frequency cavitation device with a rectangular radiating plate, which realizes the vibrations of vibrations, is considered in [25]. This intensifying method can be used to manufacture heatinsulating facade composite materials with a polymer matrix.

Summarizing the above analysis of the literature sources, it should be noted that there is no simulation of the effective parameters of the pipelines of the central water heating system and the thermal insulation of the facade for different climatic conditions. This highlights the prospect of research.

\section{Methods of research}

Fig. 1 [2] is the general scheme of the system of complex thermomodernization of the investigated building. In Fig. 1 the following designations are accepted:
1 - existing exterior (facade) wall of the thermal modern building (hereinafter - the wall);

2 - layer of equivalent facade thermal insulation (hereinafter - facade thermal insulation);

3 - adhesive layer intended for fixing the facade thermal insulation of the existing external wall;

4 - liquid coolant;

5 - layer of equivalent pipe insulation;

6 - new transit pipelines of two-pipe system of central water heating (hereinafter - pipelines);

7 - heater with side connection;

$7^{\prime}$ - heater with lower connection;

8 - distributive floor comb;

9 - new chase made in the existing wall 1 or in the facade thermal insulation 2 (hereinafter - chase);

10 - through hole in the existing wall 1;

11 - windows or translucent structures;

12 - radiator fittings;

13 - outer protective layer, protecting the facade insulation 2 against atmospheric precipitation and/or ultraviolet radiation. Roman numerals (II-XVII) in Fig. 1 designate individual elements (design solutions) of the thermomodernization system, separately investigated in [2].

Let's note that the set of essential differences described in the developed innovative technical solutions relating to the system [26] and the method of thermomodernization that realizes it [27] of considerable differences is established both experimentally and experimentally. This concerns the optimal dimensions, geometric shape, materials, composition and interrelations of the elements of the thermomodernization system. In particular, for new transit pipelines 6 two-pipe system of central water heating, equivalent to pipe insulation 5 , equivalent to facade insulation 2, forms of implementation of new chase 9 and other elements of the system. The results of the studies are presented in Table 1.

The left column of Table 1 shows the investigated indicator and its corresponding designation, and in parentheses the interval boundaries are shown in which this index varies. In columns No. 2-13 horizontally, which are both example numbers (respectively No.1-12) of the implementation of the developed technical solutions, the main parameters and material of the design of the structural elements of the thermomodernization system are given.

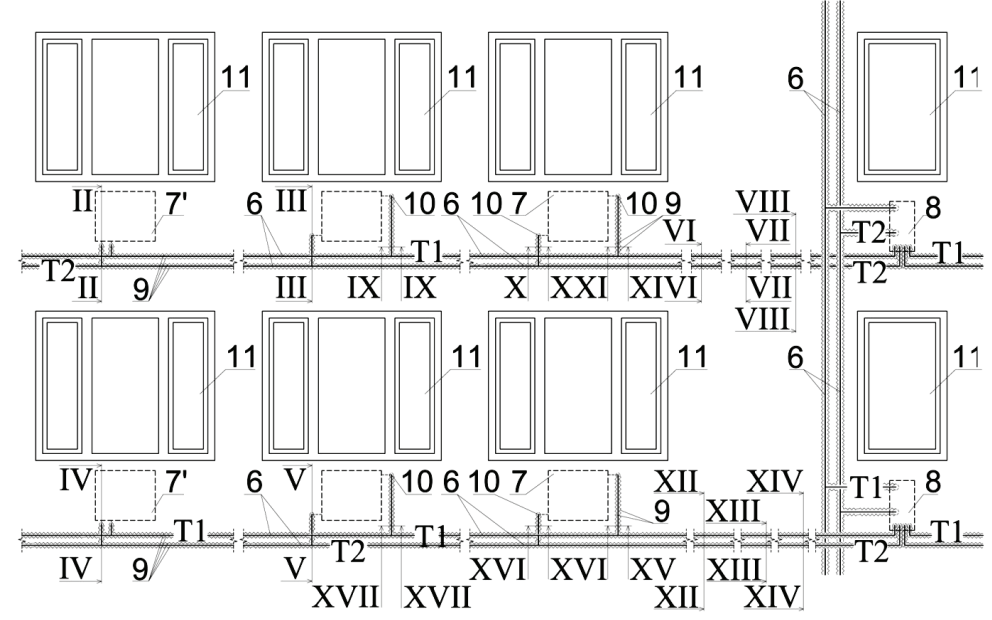

Fig. 1. General scheme of the investigated system of complex thermomodernization of buildings and structures [2] 
Basic geometric parameters, composition and material of execution of constituent elements of the thermomodernization system of buildings and structures

\begin{tabular}{|c|c|c|c|c|c|c|c|c|c|c|c|c|}
\hline \multirow{2}{*}{$\begin{array}{c}\text { Indicator (in paren- } \\
\text { theses - interval } \\
\text { boundaries) }\end{array}$} & \multicolumn{12}{|c|}{ The value of the parameter within the interval of implementation examples No. 1-12 } \\
\hline & No. 1 & No.2 & No. 3 & No. 4 & No. 5 & No. 6 & No. 7 & No. 8 & No.9 & No. 10 & No. 11 & No. 12 \\
\hline 1 & 2 & 3 & 4 & 5 & 6 & 7 & 8 & 9 & 10 & 11 & 12 & 13 \\
\hline \multicolumn{13}{|c|}{ Characteristics of the thermomodernized wall of buildings and structures and the calculated climatic conditions } \\
\hline $\begin{array}{l}\text { Coefficient of resis- } \\
\text { tance of the external } \\
\text { enclosing structure of } \\
\text { the existing external } \\
\text { wall of the thermo- } \\
\text { modernized building } \\
R_{e x,} \mathrm{~m}^{2} \cdot \mathrm{K} / \mathrm{W} \text {, } \\
(0.75-5.5) \mathrm{m}^{2} \cdot \mathrm{K} / \mathrm{W}\end{array}$ & 0.5 & 0.75 & 1 & 1.2 & 1.5 & 1.8 & 2.2 & 2.8 & 3.3 & 4.0 & 5.5 & 5.9 \\
\hline $\begin{array}{l}\text { Coefficient of resis- } \\
\text { tance of external } \\
\text { enclosing structure } \\
\text { (walls) } R_{\text {therm. } U A} ; \\
B_{\text {therm.UA }}=R_{\text {min. } U A}-R_{e x} \\
\text { at } R_{\text {min. } U A}= \\
=2.8 / 3.3\left(\mathrm{~m}^{2} \cdot \mathrm{K}\right) / \mathrm{W} \text {, } \\
\text { for the first/second } \\
\text { temperature zones, } \\
(0.5-2.8)\left(\mathrm{m}^{2} \cdot \mathrm{K}\right) / \mathrm{W}\end{array}$ & 2.3/2.8 & 2.0/2.5 & 1.8/2.3 & 1.6/2.1 & $1.3 / 1.8$ & $1.0 / 1.5$ & $0.6 / 1.1$ & $-/ 0.5$ & $-/-$ & $-1-$ & $-1-$ & $-1-$ \\
\hline $\begin{array}{l}\text { Coefficient of resis- } \\
\text { tance of external } \\
\text { enclosing structure } \\
\text { (walls) } R_{\text {therm.EU }} \\
B_{\text {therm.EU }}= \\
=A_{\text {min.EU }}-R_{\text {ex }} \\
\text { at } R_{\text {min.EU }}= \\
=2.0 / 5.9\left(\mathrm{~m}^{2} \cdot \mathrm{K}\right) / \mathrm{W} \\
(0.2-5.1)\left(\mathrm{m}^{2} \cdot \mathrm{K}\right) / \mathrm{W}\end{array}$ & $1.5 / 5.4$ & $1.2 / 5.1$ & 1.0/4.9 & $0.8 / 4.7$ & $0.5 / 4.4$ & $0.2 / 4.1$ & $-/ 3.7$ & $-/ 3.1$ & -/2.6 & $-/ 1.9$ & $-/ 0.4$ & $-1-$ \\
\hline $\begin{array}{l}\text { Coefficient of resis- } \\
\text { tance of external } \\
\text { enclosing structure } \\
\text { (walls) } R_{\text {therm.CIS }} \\
R_{\text {therm.CIS }}=B_{\text {min } I I S}-R_{\text {ex }} \\
\text { at } R_{\min . C I S}= \\
=2.0 / 5.9\left(\mathrm{~m}^{2} \cdot \mathrm{K} / \mathrm{W}\right), \\
(0.2-5.1)\left(\mathrm{m}^{2} \cdot \mathrm{K}\right) / \mathrm{W} \\
\end{array}$ & $1.5 / 5.4$ & $1.2 / 5.1$ & $1.0 / 4.9$ & $0.8 / 4.7$ & $0.5 / 4.4$ & $0.2 / 4.1$ & $-/ 3.7$ & $-/ 3.1$ & $-/ 2.6$ & $-/ 1.9$ & $-/ 0.4$ & $-/-$ \\
\hline $\begin{array}{l}\text { Minimum thickness of } \\
\text { the equivalent facade } \\
\text { insulation layer for } \\
\text { Ukraine } B_{\text {min.UA, }} \mathrm{mm} \text {, } \\
(50-250) \mathrm{mm}\end{array}$ & $100 / 150$ & $100 / 150$ & $100 / 100$ & $100 / 100$ & $50 / 100$ & $50 / 100$ & 50/50 & $-/ 50$ & $-1-$ & $-/-$ & $-1-$ & $-1-$ \\
\hline $\begin{array}{l}\text { Minimum thickness of } \\
\text { the equivalent facade } \\
\text { insulation layer for } \\
\text { CIS countries, } B_{\text {min.CIS, }} \\
\mathrm{mm},(50-250) \mathrm{mm}\end{array}$ & $100 / 250$ & $50 / 250$ & $50 / 250$ & $50 / 250$ & 50/200 & 50/200 & -/200 & $-/ 150$ & $-/ 150$ & $-/ 100$ & $-/ 50$ & $-1-$ \\
\hline $\begin{array}{l}\text { Minimum thickness } \\
\text { of the equivalent } \\
\text { facade insulation layer } \\
\text { for European Union } \\
\text { countries } V_{\text {min.EU, mm, }} \\
(50-250) \mathrm{mm}\end{array}$ & $100 / 250$ & $50 / 250$ & $50 / 250$ & $50 / 250$ & 50/200 & 50/200 & $-/ 200$ & $-/ 150$ & $-/ 150$ & $-/ 100$ & $-/ 50$ & $-/-$ \\
\hline \multicolumn{13}{|c|}{$\begin{array}{c}\text { Parameters of new transit pipelines } 6 \text { two-pipe system of central water heating, pipe thermal insulation, as well as the limiting } \\
\text { temperature conditions for the coolant }\end{array}$} \\
\hline $\begin{array}{l}\text { Outer diameter } D, \\
\text { mm, of new transit } \\
\text { pipelines of a two-pipe } \\
\text { system of central } \\
\text { water heating for } \\
\text { various materials } \\
\text { of their execution, } \\
\text { (7-114) mm, with } \\
\text { a wall thickness } \\
(0.7-22.1) \mathrm{mm}\end{array}$ & 6 & $7-12$ & $13-18$ & 19-25 & 26-32 & $33-40$ & $41-50$ & $51-57$ & $58-75$ & $76-85$ & 86-114 & 140 \\
\hline
\end{tabular}


Continuation of Table 1

\begin{tabular}{|c|c|c|c|c|c|c|c|c|c|c|c|c|}
\hline 1 & 2 & 3 & 4 & 5 & 6 & 7 & 8 & 9 & 10 & 11 & 12 & 13 \\
\hline $\begin{array}{l}\text { The existing diameter } \\
\text { of pipelines of cross- } \\
\text { linked polyethylene } \\
\text { (PEX) } D_{p e x} \text { mm, indi- } \\
\text { cating the thickness of } \\
\text { the wall }\end{array}$ & - & $12 \times 2.0$ & $\begin{array}{c}14 \times 2.0 ; \\
14 \times 2.25 ; \\
16 \times 2.0 ; \\
16 \times 2.2 ; \\
16 \times 2.6 ; \\
18 \times 2.0 \\
18 \times 2.5\end{array}$ & $\begin{array}{l}20 \times 2.8 ; \\
20 \times 2.9 ; \\
25 \times 2.3 ; \\
25 \times 3.5 ; \\
25 \times 3.7\end{array}$ & $\begin{array}{l}32 \times 2.9 ; \\
32 \times 4.4 ; \\
32 \times 4.7\end{array}$ & $\begin{array}{l}40 \times 3.7 \\
40 \times 5.5 ; \\
40 \times 6.0\end{array}$ & $\begin{array}{l}50 \times 4.6 ; \\
50 \times 6.9\end{array}$ & - & $\begin{array}{l}63 \times 5.8 \\
63 \times 8.6 \\
63 \times 8.7\end{array}$ & $\mid \begin{array}{c}14 \times 2.0 ; \\
14 \times 2.25 ; \\
16 \times 2.0 ; \\
16 \times 2.2 ; \\
16 \times 2.6 ; \\
18 \times 2.0 \\
18 \times 2.5\end{array}$ & $\begin{array}{c}90 \times 8.2 ; \\
110 \times 10.0\end{array}$ & - \\
\hline $\begin{array}{l}\text { The existing diameters } \\
\text { of pipelines made } \\
\text { of multi-layer metal } \\
\text { plastic } D_{\text {met.plast., mm, }} \\
\text { indicating the thick- } \\
\text { ness of the wall }\end{array}$ & - & - & $\begin{array}{c}14 \times 2.0 ; \\
16 \times 2.0 ; \\
16 \times 2.7 ; \\
16.2 \times 2.6\end{array}$ & $\begin{array}{c}20 \times 2.0 ; \\
20 \times 2.25 ; \\
20 \times 2.9 ; \\
20 \times 3.3 ; \\
25 \times 2.5 ; \\
25 \times 3.7 ; \\
25 \times 4.0\end{array}$ & $\begin{array}{l}26 \times 2.0 ; \\
26 \times 3.0 ; \\
32 \times 3.0 ; \\
32 \times 4.0 ; \\
32 \times 4.4\end{array}$ & $\begin{array}{l}40 \times 3.5 \\
40 \times 4.0\end{array}$ & $50 \times 4.5$ & - & $\begin{array}{l}63 \times 4.5 ; \\
63 \times 6.0\end{array}$ & $\begin{array}{c}75 \times 5.0 \\
75 \times 7.5\end{array}$ & $\begin{array}{c}90 \times 8.5 ; \\
110 \times 10.0\end{array}$ & - \\
\hline $\begin{array}{l}\text { The existing diameters } \\
\text { of pipelines of steel } \\
D_{\text {steel }}, \text { mm, indicat- } \\
\text { ing the thickness of } \\
\text { the wall }\end{array}$ & - & $12 \times 1.2$ & $\begin{array}{l}15 \times 1.2 ; \\
18 \times 1.2\end{array}$ & $22 \times 1.5$ & $28 \times 1.5$ & $35 \times 1.5$ & $42 \times 1.5$ & $54 \times 1.5$ & $\begin{array}{c}64 \times 1.5 \\
66.7 \times 1.5\end{array}$ & $76.1 \times 2.0$ & $\begin{array}{c}88.9 \times 2.0 ; \\
108 \times 2.0\end{array}$ & - \\
\hline $\begin{array}{l}\text { The existing diameters } \\
\text { of pipelines of black } \\
\text { steel } D_{\text {black steel, }} \text { mm, } \\
\text { indicating the thick- } \\
\text { ness of the wall }\end{array}$ & - & $\begin{array}{l}10.2 \times 1.8 ; \\
10.2 \times 2.0 ; \\
10.2 \times 2.5\end{array}$ & $\begin{array}{c}13.5 \times 2.0 ; \\
13.5 \times 2.2 ; \\
13.5 \times 2.8 ; \\
17 \times 2.0 ; \\
17 \times 2.2 ; \\
17 \times 2.8\end{array}$ & $\begin{array}{l}21.3 \times 2.5 ; \\
21.3 \times 2.8 \\
21.3 \times 3.2\end{array}$ & $\begin{array}{l}26.8 \times 2.5 ; \\
26.8 \times 2.8 ; \\
26.8 \times 3.2\end{array}$ & $\mid \begin{array}{l}33.5 \times 2.8 ; \\
33.5 \times 3.2 ; \\
33.5 \times 4.0\end{array}$ & $\mid \begin{array}{c}42.3 \times 2.8 ; \\
42.3 \times 3.2 ; \\
42.3 \times 4.0 ; \\
48 \times 3.0 ; \\
48 \times 3.5 ; \\
48 \times 4.0\end{array}$ & - & $\begin{array}{r}60 \times 3.0 ; \\
60 \times 3.5 ; \\
60 \times 4.5 ; \\
75.5 \times 3.2 ; \\
75.5 \times 4.0 ; \\
75.7 \times 4.5\end{array}$ & - & \begin{tabular}{|c|}
$88.5 \times 3.5 ;$ \\
$88.5 \times 4.0 ;$ \\
$88.5 \times 4.5 ;$ \\
$101.3 \times 3.5 ;$ \\
$101.3 \times$ \\
$4.0101 .3 \times$ \\
$4.5114 \times 4.0 ;$ \\
$114 \times 4.5 ;$ \\
$114 \times 5.0$
\end{tabular} & $\begin{array}{c}140 \times \\
4.0140 \times \\
4.5 \\
140 \times 5.5\end{array}$ \\
\hline $\begin{array}{l}\text { The existing diameters } \\
\text { of pipelines of stain- } \\
\text { less steel } D_{\text {st. steel, }}, \mathrm{mm} \text {, } \\
\text { indicating the thick- } \\
\text { ness of the wall }\end{array}$ & - & - & $\begin{array}{l}15 \times 1.0 ; \\
18 \times 1.0\end{array}$ & $22 \times 1.2$ & $28 \times 1.2$ & $35 \times 1.5$ & $42 \times 1.5$ & $54 \times 1.5$ & - & $76.1 \times 2.0$ & $\begin{array}{c}88.9 \times 2.0 \\
108 \times 2.0\end{array}$ & - \\
\hline $\begin{array}{l}\text { The existing diameters } \\
\text { of copper pipelines, } \\
D_{\text {cop, }} \text { mm, indicating } \\
\text { the thickness of the } \\
\text { wall }\end{array}$ & $6 \times 1.0$ & $\begin{array}{c}8 \times 1.0 ; \\
10 \times 1.0 ; \\
12 \times 0.7 ; \\
12 \times 1.0\end{array}$ & $\begin{array}{l}14 \times 0.8 \\
15 \times 1.0 ; \\
16 \times 2.0 ; \\
18 \times 1.0\end{array}$ & $22 \times 1.0$ & $28 \times 1.0$ & $35 \times 1.0$ & $42 \times 1.5$ & $\begin{array}{l}54 \times 1.5 ; \\
54 \times 2.0\end{array}$ & $64 \times 2.0$ & $76 \times 2.0$ & $\begin{array}{l}89 \times 2.0 ; \\
108 \times 2.5\end{array}$ & - \\
\hline $\begin{array}{l}\text { The existing diameters } \\
\text { of pipelines fram } \\
\text { polypropylene } D_{p p} \\
\text { mm, indicating the } \\
\text { thickness of the wall }\end{array}$ & - & - & $\begin{array}{l}16 \times 2.2 ; \\
16 \times 2.3 ; \\
16 \times 2.7\end{array}$ & $\begin{array}{l}20 \times 1.9 ; \\
20 \times 2.3 ; \\
20 \times 2.8 ; \\
20 \times 3.2 ; \\
20 \times 3.4 ; \\
20 \times 4.1 ; \\
25 \times 2.3 ; \\
25 \times 2.8 ; \\
25 \times 3.5 ; \\
25 \times 4.2 ; \\
25 \times 5.1\end{array}$ & $\begin{array}{l}32 \times 2.9 ; \\
32 \times 3.6 ; \\
32 \times 4.4 ; \\
32 \times 4.5 ; \\
32 \times 5.4 i \\
32 \times 6.5\end{array}$ & $\begin{array}{l}40 \times 3.7 ; \\
40 \times 4.5 ; \\
40 \times 5.5 ; \\
40 \times 5.6 ; \\
40 \times 6.7 ; \\
40 \times 8.1\end{array}$ & $\begin{array}{l}50 \times 4.6 ; \\
50 \times 5.6 ; \\
50 \times 6.1 ; \\
50 \times 6.9 ; \\
50 \times 8.3 ; \\
50 \times 8.4 ; \\
50 \times 10.1\end{array}$ & - & \begin{tabular}{|c|}
$63 \times 5.8 ;$ \\
$63 \times 7.1 ;$ \\
$63 \times 7.8 ;$ \\
$63 \times 8.6 ;$ \\
$63 \times 8.7 ;$ \\
$63 \times 10.5 ;$ \\
$63 \times 12.7 ;$ \\
$75 \times 6.8 ;$ \\
$75 \times 8.4 ;$ \\
$75 \times 9.5 ;$ \\
$75 \times 10.3 ;$ \\
$75 \times 10.4 ;$ \\
$75 \times 12.5 ;$ \\
$75 \times 15.1$
\end{tabular} & - & $\begin{array}{c}90 \times 8.2 ; \\
90 \times 10.1 ; \\
90 \times 12.3 ; \\
90 \times 12.5 ; \\
90 \times 15.0 ; \\
90 \times 18.1 ; \\
110 \times 10.0 ; \\
110 \times 12.3 ; \\
110 \times 15.1 ; \\
110 \times 15.2 ; \\
110 \times 18.3 ; \\
110 \times 18.4 ; \\
110 \times 22.1\end{array}$ & - \\
\hline $\begin{array}{l}\text { The existing diameters } \\
\text { of pipelines from poly- } \\
\text { butylene, } D_{\text {polybutrlene, }} \\
\text { mm, indicating the } \\
\text { thickness of the wall }\end{array}$ & - & - & $15 \times 1.75$ & $22 \times 2.15$ & $28 \times 2.65$ & - & - & - & - & - & - & - \\
\hline $\begin{array}{l}\text { Execution mate- } \\
\text { rial of equivalent pipe } \\
\text { insulation }\end{array}$ & $\begin{array}{l}\text { no insu- } \\
\text { lation }\end{array}$ & $\begin{array}{c}\text { foam poly- } \\
\text { ethylene/ } \\
\text { rubber/ } \\
\text { corrugated } \\
\text { thermal } \\
\text { insulation }\end{array}$ & $\begin{array}{c}\text { foam } \\
\text { poly- } \\
\text { ethylene/ } \\
\text { rubber/ } \\
\text { cor- } \\
\text { rugated } \\
\text { thermal } \\
\text { insulation }\end{array}$ & $\begin{array}{c}\text { foam poly- } \\
\text { ethylene/ } \\
\text { rubber/ } \\
\text { corrugated } \\
\text { thermal } \\
\text { insulation }\end{array}$ & \begin{tabular}{|} 
foam poly- \\
ethylene/ \\
rubber/ \\
corrugated \\
thermal \\
insulation
\end{tabular} & \begin{tabular}{|c|} 
foam \\
poly- \\
ethylene/ \\
rubber/ \\
corrugated \\
thermal \\
insulation
\end{tabular} & $\begin{array}{c}\text { foam } \\
\text { poly- } \\
\text { ethylene/ } \\
\text { rubber/ } \\
\text { cor- } \\
\text { rugated } \\
\text { thermal } \\
\text { insulation }\end{array}$ & $\begin{array}{c}\text { foam } \\
\text { poly- } \\
\text { ethylene/ } \\
\text { rubber/ } \\
\text { cor- } \\
\text { rugated } \\
\text { thermal } \\
\text { insulation }\end{array}$ & \begin{tabular}{|c|} 
foam \\
poly- \\
ethylene/ \\
rubber/ \\
cor- \\
rugated \\
thermal \\
insulation
\end{tabular} & $\begin{array}{c}\text { foam } \\
\text { poly- } \\
\text { ethylene/ } \\
\text { rubber/ } \\
\text { cor- } \\
\text { rugated } \\
\text { thermal } \\
\text { insulation }\end{array}$ & $\begin{array}{c}\text { foam poly- } \\
\text { ethylene/rub- } \\
\text { ber/corru- } \\
\text { gated thermal } \\
\text { insulation }\end{array}$ & $\begin{array}{c}\text { no insu- } \\
\text { lation }\end{array}$ \\
\hline
\end{tabular}


Continuation of Table 1

\begin{tabular}{|c|c|c|c|c|c|c|c|c|c|c|c|c|}
\hline 1 & 2 & 3 & 4 & 5 & 6 & 7 & 8 & 9 & 10 & 11 & 12 & 13 \\
\hline \begin{tabular}{|l} 
The thickness of the \\
layer of equivalent \\
pipe thermal insulation \\
$\delta_{T,}$ mm (expanded \\
polyethylene/rub- \\
ber/corrugated), \\
$(6-50)$ mm
\end{tabular} & $-/-/-$ & $6 / 6 / 4$ & $9 / 9 / 4$ & $13 / 13 / 6$ & 13/13/6 & $15 / 15 / 6$ & $20 / 19 / 6$ & $22 / 25 / 6$ & 28/32/6 & $35 / 40 / 6$ & 42/50/6 & $-/-/-$ \\
\hline $\begin{array}{l}\text { Estimated difference } \\
\text { of coolant tempera- } \\
\text { tures in the supply and } \\
\text { return pipes } \Delta T \text {, }{ }^{\circ} \text {, } \\
(10-25)^{\circ} \mathrm{C}\end{array}$ & 5 & \multicolumn{10}{|c|}{$10-25$} & 30 \\
\hline $\begin{array}{l}\text { The time to reach the } \\
\text { temperature of the } \\
\text { coolant is } 0 \text { ० } \mathrm{C} \text { with } \\
\text { thickness of equivalent } \\
\text { thermal insulation } \\
\text { layer } B_{\min }=50 \mathrm{~mm} \text {, } \\
t_{50}, \mathrm{~h},(8-19) \mathrm{h}\end{array}$ & 20 & 19 & 17 & 16 & 15 & 14 & 13 & 12 & 11 & 10 & 8 & 6 \\
\hline $\begin{array}{l}\text { Time to reach coolant } \\
\text { temperature } 0 \text { ' } \mathrm{C} \text { at } \\
\text { a thickness of thermal } \\
\text { insulation equivalent } \\
\text { layer } B=100 \mathrm{~mm}, \\
t_{100}, \mathrm{~h}\end{array}$ & \multicolumn{12}{|c|}{ freezing of the coolant does not occur } \\
\hline \multicolumn{13}{|c|}{ Variants of placement and fastening of pipelines of two-pipe heating system } \\
\hline $\begin{array}{l}\text { In the chase, made in } \\
\text { the existing wall from } \\
\text { the side of its fas- } \\
\text { tening to the equivalent } \\
\text { facade thermal insula- } \\
\text { tion/(in the chase, } \\
\text { made in an equivalent } \\
\text { facade insulation, from } \\
\text { the side of its attach- } \\
\text { ment to the existing } \\
\text { external wall) }\end{array}$ & no/yes & yes/yes & yes/yes & yes/yes & yes/yes & yes/yes & yes/yes & yes/no & yes/no & yes/no & yes/no & no/yes \\
\hline Chase form & $\begin{array}{c}\text { no/no/ } \\
\text { no }\end{array}$ & $\begin{array}{c}\text { yes/yes/ } \\
\text { yes }\end{array}$ & $\begin{array}{c}\text { yes/yes/ } \\
\text { yes }\end{array}$ & $\begin{array}{c}\text { yes/yes/ } \\
\text { yes }\end{array}$ & $\begin{array}{c}\text { yes/yes/ } \\
\text { yes }\end{array}$ & $\begin{array}{c}\text { yes/yes/ } \\
\text { yes }\end{array}$ & $\begin{array}{c}\text { yes/yes/ } \\
\text { yes }\end{array}$ & $\begin{array}{c}\text { no/no/ } \\
\text { yes }\end{array}$ & $\begin{array}{c}\text { yes/no/ } \\
\text { yes }\end{array}$ & $\begin{array}{c}\text { yes/no/ } \\
\text { no }\end{array}$ & $\begin{array}{c}\text { no/yes/ } \\
\text { no }\end{array}$ & $\begin{array}{c}\mathrm{no} / \mathrm{no} / \\
\text { no }\end{array}$ \\
\hline \begin{tabular}{|l} 
Optimum depth \\
(height) of the chase \\
$B_{D}, \mathrm{~mm}(25-155) \mathrm{mm}$
\end{tabular} & 10 & 25 & 36 & 43 & 50 & 60 & 90 & 100 & 115 & 125 & 155 & 180 \\
\hline $\begin{array}{l}\text { The optimum width } \\
\text { of the chase } B_{s}, \mathrm{~mm} \\
\text { (50-310) } \mathrm{mm}\end{array}$ & 20 & 50 & 72 & 86 & 100 & 120 & 180 & 200 & 230 & 250 & 310 & 360 \\
\hline
\end{tabular}

\section{Research results}

6.1. Thickness of the facade insulation layer. As a result of the conducted studies, it is found that deviations from the optimal sizes and effective materials lead to a deterioration in the parameters of the elements of the thermomodernization system. Namely, to the high heat losses, the breaking of the bearing capacity of the existing facade walls), the thermomodernized building, the high hydraulic resistance in the pipelines 6 , the freezing potential of the coolant 4. The thermal expansion of the pipelines 6 is also not adversely affected by the integrity of the facade thermal insulation layer 2 (the extreme examples of the implementation No. 1, No. 12 in Table 1). For example, it has been experimentally established that a decrease in the thickness $B_{\min }$ of the facade thermal insulation layer 2 is less than the optimum value results in a decrease in the heat transfer resistance coefficient $R_{\text {min }}$. With $B_{\min }=50 \mathrm{~mm}$, the coefficient $R_{\min }=1.32\left(\mathrm{~m}^{2} \cdot \mathrm{K}\right) / \mathrm{W}$, and at $B_{\min }=150 \mathrm{~mm}$ the coefficient $R_{\min }=3.65\left(\mathrm{~m}^{2} \cdot \mathrm{K}\right) / \mathrm{W}$. This, in turn, increases 2.7 times the thermal losses of the thermomodernized building and pipelines 6 and leads to a decrease in the temperature of the heat-transfer medium 4 entering the consumers. The absence of movement of the coolant 4 in the pipelines 6 can lead to its freezing and to a violation of the integrity of the pipelines 6 .

At the same time, an increase in the thickness $B_{\text {min }}$ more than the optimal value for the first and second temperature zone of Ukraine leads to an increase in the resistance coefficient $R_{\min }$ in excess of the minimum required 
resistance coefficient $R_{\text {min.UA }}$, which is not a violation. The latter is installed according to the DBN [4] for different temperature zones of Ukraine. However, the use of a facade thermal insulation 2 with a thickness of $B_{\min }$ of more than $150 \mathrm{~mm}$ increases the cost of materials and installation work, not in proportion to the increase in the coefficient of heat transfer resistance $R_{\min }$.

6.2. The value of the diameter of the pipelines. Table 1 shows diameters $D$ of industrially produced pipelines for a more accurate determination of the depth of the required chase 9 in the existing wall 1 or in the material of the facade insulation 2 . The ratio of the diameters $D$ of the used pipelines 6 of the heating system to the thickness $\delta_{T}$ of equivalent pipe insulation 5 and to the depth $B_{D}$ of the executable chase 9 allows dividing them for several calculated cases.

In Table 1 in the columns for the values of pipe diameters $D$ for different materials, the values «external diameter» $\times$ «thickness» are indicated, after which the indicated values of all sizes used today. And for the values of the diameters $D$ of the pipelines 6 , which are indicated in the form of a range, the range boundaries indicate the minimum and maximum values of the values.

It has also been experimentally established that a decrease in the diameters $D$ of the pipelines 6 and the calculated difference in temperature $\Delta T$ between the feed and return pipelines 6 leads to an increase in the velocity of the coolant 4. As a result, the hydraulic resistance in the pipelines 6 of the thermomodernized building increases. This, in turn, leads to the need to use pumps with increased power characteristics, and also increases the capital and operating costs necessary for the stable operation of a twopipe central heating system.

At the same time, an increase in the diameters $D$ and the calculated temperature difference $\Delta T$ between the supply and return lines 6 results in a decrease in the velocity of the heat coolant 4. This can lead to an increase in the depth $b$ of the chase 9 , that is, it may negatively affect the load-bearing capacity of the thermomodernized building.

Replacing the existing (single-pipe) piping system with new transit pipelines 6 of two-pipe central heating with optimal parameters and heater of the 7 and $7^{\prime}$ heating system gives the following advantages. This is, first of all, the ability to design a two-pipe system of central water heating between a high- and low-temperature heat sources. This, in turn, expands the application of various heat sources, such as heat pumps and renewable energy sources, that is, to diversify the heat sources used. Also, the use of a two-pipe heating system as part of a complex thermomodernization system allows accounting and regulation of consumed heat by each consumer.

6.3. Pipeline placement in chases. Notation in Table 1 «in a chase made in an existing wall/(chase, made in an equivalent facade insulation)» means the laying of pipelines 6 or in the chase 9 , or directly in the wall 1 , or in the layer of facade thermal insulation 2. The forms of execution chase 9 are listed in Table 1 through the fraction sign «/», namely it can be «rectangular/triangular/arched».

The choice of the concrete form of execution of the new chase 9 is determined by the design features of the existing wall 1 of the thermomodernized building in the place of its attachment to the heater $7,7^{\prime}$. At the same time, the selection of the equipment that is carried out by the work chase (wall chaser, sanding machine for con- crete, the use of mechanisms in which the cutting edge is a diamond cable) also influences the choice of the shape of the new chase 9 .

According to the developed technical solution, the maximum depth $b$ of the chase 9 in the wall 1 varies within the range $B_{D}=(25-155) \mathrm{mm}$. This value $B_{D}$ is selected depending on the diameters $D$ of the pipelines 6 , which will be laid in the chase 9 , and the thickness $\delta_{T}$ of the layer of the pipe thermal insulation 5, must be completely placed in the completed chase 9 .

At the same time, the location of the pipelines 6 in the chases 9 that are performed in the layer of the facade insulation 2 creates the risk that the thermal expansion of the pipelines 6 extends the straight sections of the pipelines 6 . As a result, the stress within the building structure increases. This can lead to loss of tightness of the facade thermal insulation layer 2 and, as a consequence, to deterioration of the thermal characteristics of the thermomodernized building.

The arrangement of the pipelines 6 in the chases 9 made in the wall 1 allows the loads resulting from the thermal elongation of the pipes 6 to be redistributed to the existing building structure. This, in turn, allows to increase the energy efficiency and density of the building structure, as well as to avoid the violation of the integrity of the facade thermal insulation layer 2 of the thermomodernized building.

6.4. The value of the thermal conductivity coefficient. The coefficient of resistance of the external enclosing structure of the wall 1 of the thermomodernized building varies within the limits of $R_{e x}=(0.75-5.5) \mathrm{m}^{2} \cdot \mathrm{K} / \mathrm{W}$. It is established that a deviation from the lower value of this optimal parameter leads to a decrease in the efficiency of the thermal building modernization system. This is due to the fact that the walls of 1 building with a lower coefficient of resistance to thermal conductivity $R_{\min }, 0.75 \mathrm{~m}^{2} \cdot \mathrm{K} / \mathrm{W}$, it is more appropriate to replace completely than to perform their thermal upgrading.

At the same time deviations from the upper value of the optimal parameter $R_{e x}$ leads to a decrease in the efficiency of the thermal building modernization system. This is due to the fact that the walls of 1 building already have the minimum required coefficient of thermal conductivity $R_{\min . U A}$ for the specified region, and therefore do not require additional insulation.

The coefficient of necessary resistance of the external enclosing structure $R_{\text {therm.UA }}$ for thermal building modernization, according to the developed technical solutions, is calculated as follows: K/W. Applying the above expression, a range of values from $0.5 \mathrm{~m}^{2} \cdot \mathrm{K} / \mathrm{W}$ to $2.8 \mathrm{~m}^{2} \cdot \mathrm{K} / \mathrm{W}$ is obtained, which stipulate the minimum required values of the $R_{\text {min.UA }}$ coefficient.

The coefficient of resistance of thermal conductivity $R_{\text {min.UA }}$ is applied in Ukraine and depends on the applied temperature zone according to DBN B.2.6-31:2016 [10]. So, for the first temperature zone, the coefficient $R_{\text {min.UA }}=$ $=3.3 \mathrm{~m}^{2} \cdot \mathrm{K} / \mathrm{W}$, for the second temperature zone the coefficient $R_{\min . U A}=2.8 \mathrm{~m}^{2} \cdot \mathrm{K} / \mathrm{W}$. Table 1 shows the values of $R_{\text {min.UA }}$ for the first and second zones through the «/» sign.

The coefficient of the required resistance of the external enclosing structure of the EU countries $R_{\text {therm.EU }}$ for the complex thermomodernization of the building is calculated according to the following formula: $R_{\text {therm.EU }}=R_{\min . E U}-R_{e x}$, and varies within $R_{\text {therm. } E U}=(0.2-5.1) \mathrm{m}^{2} \cdot \mathrm{K} / \mathrm{W}$. Applying 
the above expression, a range of values of $0.2 \mathrm{~m}^{2} \cdot \mathrm{K} / \mathrm{W}$ to $5.1 \mathrm{~m}^{2} \cdot \mathrm{K} / \mathrm{W}$ is obtained, resulting in the minimum required values of the coefficient $R_{\min . E U}$.

The coefficient of necessary resistance of the external enclosing structure $R_{\min . E U}$ depends on the climatic conditions of different countries. Thus, for warm countries (Italy, Hungary, etc.), the coefficient $R_{\min . E U}=2.0 \mathrm{~m}^{2} \cdot \mathrm{K} / \mathrm{W}$, for cold countries (Norway, Sweden, Finland) the coefficient $R_{\min . E U}=5.9 \mathrm{~m}^{2} \cdot \mathrm{K} / \mathrm{W}$. Table 1 shows the values of $R_{\min . E U}$ through the «/» sign.

The coefficient of the required resistance of the outer enclosing structure $R_{\text {therm.CIS }}$ for the complex thermal building of the building is calculated as follows: $R_{\text {therm.CIS }}=$ $=R_{\min C I S}-R_{e x}$, and varies within $(0.2-5.1) \mathrm{m}^{2} \cdot \mathrm{K} / \mathrm{W}$. Applying the above formula, a range of $R_{\text {therm.CIS }}$ values of $0.2 \mathrm{~m}^{2} \cdot \mathrm{K} / \mathrm{W}$ to $5.1 \mathrm{~m}^{2} \cdot \mathrm{K} / \mathrm{W}$ is obtained, which stipulate the minimum required values of the $R_{\text {tminCIS }}$ coefficient.

The coefficient of necessary resistance of the external enclosing structure $R_{\min . C I S}$ is used in the CIS countries and depends on the climatic conditions of different countries and/or regions. So, for warm regions, such as the Krasnodar Krai of the Russian Federation, the coefficient $R_{\text {min.CIS }}=2.0 \mathrm{~m}^{2} \cdot \mathrm{K} / \mathrm{W}$, for cold regions such as the Far North, the coefficient $R_{\text {min. CIS }}=5.9 \mathrm{~m}^{2} \cdot \mathrm{K} / \mathrm{W}$. Table 1 shows the values of $R_{\min . C I S}$ and their derivatives through the fraction sign «/».

6.5. An example of thermomodernization of a building. After carrying out the analysis of the technical condition of the thermomodernized building, including the energy audit of the building and the analysis of the serviceability and technical condition of the existing heating system of the building, design of the individual elements and the entire system of thermomodernization is done as a whole.

In particular, when examining the distribution of the temperature field inside a building structure, that is, when considering the thermal problem, it is assumed that the pipelines 6 and the wall 1 are covered with a layer of facade thermal insulation 2 with a variable thickness $B_{\min }$. The result is a change in the temperature $T$ on the (external) surface of the facade thermal insulation 2 from the minimum to the maximum value determined in accordance with the DBN [10].

Also, to predict the performance of the projected heating system, the limiting drop in the temperature of the heat coolant 4 with time is examined in the case of a stoppage of the coolant 4 in the pipelines 6 at a variable thickness of the layer of equivalent thermal insulation $B_{\text {min }}$

It is established that in example No. 4 of Table 1 (Kyiv, Ukraine, design temperature $T=-22{ }^{\circ} \mathrm{C}$ ) time to reach coolant 4 temperature $0{ }^{\circ} \mathrm{C}$ with a thickness of the facade insulation layer $B_{\min }=50 \mathrm{~mm}$ is $t_{50}=16 \mathrm{~h}$. And with the thickness of the facade insulation layer $B_{\min }=100 \mathrm{~mm}$ of freezing of the coolant 4 does not occur.

The above studies have made it possible to determine the optimal parameters and material for the execution of structural elements of the building's thermomodernization system, which are given below, by carrying out studies using the procedure given in [2]. The values indicated in Table 1 are also taken into account (in this case this is an example of No. 4).

As a thermal technical parameter, the coefficient of resistance of the outer enclosing structure (wall 1) was chosen, namely $R_{e x}=1.2\left(\mathrm{~m}^{2} \cdot \mathrm{K}\right) / \mathrm{W}$. The coefficient of resistance of the external enclosing structure (wall 1) is
$R_{\text {term.UA }}=1.6 / 2.1\left(\mathrm{~m}^{2} \cdot \mathrm{K}\right) / \mathrm{W}$ (respectively for the first $/ \mathrm{sec}$ ond temperature zones of Ukraine), which determines the thickness $B_{\min }$ of the facade insulation. The calculated temperature difference of the heat coolant 4 in the supply and return lines 6 in this example is $\Delta T=20^{\circ} \mathrm{C}$.

To optimize the thickness of the facade insulation layer $2 B_{\min }$, two options for the placement of pipelines 6 are also investigated. Option No. 1, where the pipelines 6 are located in a chase 9, made in the wall 1 from the side of its attachment to the facade thermal insulation 2 . Option No. 2, where the pipelines 6 are placed in the chase 9 , made in the facade insulation 2 on the side of its attachment to the wall 1.

In this case, variants No. 1 and No. 2 are examined with a variation in the thickness $B_{\min }$. The conducted studies confirmed the value of $B_{\min }=100 \mathrm{~mm}$.

In Example No.4, the material of pipelines 6 is polypropylene; the outer diameter of the pipelines 6 is $D=20 \mathrm{~mm}$, the thickness of their walls is $\delta=2.8 \mathrm{~mm}$; the thickness of the layer of pipe thermal insulation 5 of the pipelines 6 is $\delta_{T}=13 \mathrm{~mm}$.

After determining the location of the heaters $7,7^{\prime}$, the distribution combs 8 . Next, the laying routes in which the pipes 6 are placed in the chase 9 made in the walls 1 from the fastening side to the facade insulation 2 and the laying routes in which the pipes 6 are positioned in the chases 9, made in the facade insulation 2 on the side of its attachment to the wall 1.

Pipeline laying routes 6 are carried out taking into account the technical possibility of wall chasing 9 in the walls 1 from the fastening side to the facade insulation 2 without affecting the bearing capacity of the building. Chases 9 perform a rectangular shape in the form of one versatile rectangle. Thus, the laying of the pipelines 6 is carried out in pants, namely in the chases 9 made both in the existing outer wall 1 from the side of its fastening to the facade thermal insulation 2 and in the facade thermal insulation 2 from the side of its fastening to the wall 1.

After that, the heating system is installed. In particular, after the laying of pipelines 6 , the heaters $7,7^{\prime}$ are installed inside the rooms. After this, hydraulic testing of pipelines 6 is carried out, which allows to determine possible leaks of these pipelines and to eliminate the leakage of the heating system.

Then the pipelines 6 are covered with a layer of pipe insulation 5 made of expanded polyethylene and a thickness of $\delta_{T}$, which varies within $13 \mathrm{~mm}$.

After successful completion of the hydraulic tests, the pipelines 6 , covered with a layer of pipe insulation 5 , together with the walls 1 , are covered with a layer of facade thermal insulation 2 with a thickness $B_{\min }=100 \mathrm{~mm}$.

In this example, the facade insulation system of the exterior walls of buildings and structures is performed in the form of a «wet facade» with the use of the basic material of foam PSB-S-25 insulation and mineral cotton wool in the form of firemen, rosette around windows and on the facade. In this case, the insulation of the facade of the thermomodernized building is made in the form of slabs, which are fixed with adhesive mortars and dowels to the existing outer wall 1 . Then the slab is covered with a plaster layer with reinforcing mesh, which is made of high-strength and simultaneously inert material in the form of glass fibers. 


\section{SWOT analysis of research results}

Strengths. Compared with analogues, the positive effect of the research object in the form of constituent elements of the thermomodernization system lies in the long-term optimization of organizational and technical solutions for improving the energy efficiency of Ukrainian buildings and facilities for various climatic conditions. This includes modeling the effective parameters of the pipelines of the central water heating system and the thermal insulation of the facade.

Weaknesses. To the weak sides of the proposed effective parameters and materials for the execution of pipelines for the central water heating system and for the thermal insulation of the facade, the need for initial capital investments in the system of new transit pipelines for water heating and facade thermal insulation can be attributed to thermomodernization of buildings and structures. It is also unbearable to provide for the costs of their installation at the location of buildings and structures. Also, the weaknesses of the proposed solutions include their locality («pointing») with respect to the entire complex system of thermomodernization and the lack of consideration of the interaction of all the constituent elements of the thermomodernization system.

Opportunities. The proposed technical solutions for improving the energy efficiency of buildings and structures contribute to reducing heat consumption during the heating season. This, in turn, will significantly reduce the amount of utility payments for heating both for the population and for industrial enterprises. The expected profit is forecasted to be obtained in about $2-3$ years, depending on the number of thermomodernized objects.

Threats. From the enterprise or the operating organization will require initial capital investment in new transit pipelines and water heating in the facade insulation. Also, the costs of their installation at the location of thermomodernized buildings and structures are required.

Adverse effects on the object of research in the form of external factors of the environment and other operating conditions due to regulatory-life of thermal insulation and facade systems new transit water heating piping. This depends on the materials and climatic zones used for the operation of thermomodernized buildings and structures. However, this period shall be at least 20 years, which is more than sufficient for self-sufficiency developed organizational and technical solutions for thermomodernization. The latter are protected by patents of Ukraine for inventions for the method and device that confirms their innovativeness among similar world prototypes.

\section{Conclusions}

1. As a result of the experimentally-numerous and calculated studies, effective design parameters and material for the execution of pipelines for the central water heating system have been substantiated to significantly reduce the energy consumption of existing buildings and structures of the Ukrainian housing stock. It is established that the deviation from the optimum sizes and effective materials for the execution of the elements of the thermomodernization system, determined experimentally and by calculation, leads to high thermal losses, the breaking of the bearing capacity of the existing facade walls of the thermomodernized building. No less negative consequence is the high hydraulic resistance in pipelines, the possibility of freezing in them of the heat coolant, and the thermal expansion of pipelines and disruption of the integrity of the facade thermal insulation layer.

The minimum thickness of the facade thermal insulation layer is determined to be $50 \mathrm{~mm}$ for the temperature and operating conditions under study, as well as for the characteristics of the used materials, the geometry of the pipelines and the facade thermal insulation for the first temperature zone.

2. Effective design parameters and material for the performance of thermal insulation are found. The resulting optimum thickness of the facade thermal insulation layer is $100 \mathrm{~mm}$, and results in $100 \%$ protection against freezing of the pipelines, even if the coolant is completely stopped for more than 24 hours after the coolant ceases to flow. It is noted that, given the insignificant weight of the application of the facade insulation, there is no need to strengthen the load-bearing structures of the thermounderdetermined building. Fastenings of front thermal insulation and pipelines of two-pipe system of water heating are carried out with the help of glutinous mixtures and «umbrella fasteners». Thanks to this, a constant microclimate inside the premises is ensured, that is, comfortable working or living conditions.

3. Modeling of effective parameters of pipelines of the central water heating system and thermal insulation of the facade for different climatic conditions. The results of the simulation are expediently permissible in both Ukrainian and foreign organizations, which serve these buildings and structures. The obtained results expand the geographic boundaries of the application of the developed technical solutions that emphasize the prospects of the research direction of thermomodernization and its export orientation.

\section{References}

1. Yeromin A., Kolosov A. Choice and ground for direction of energy efficiency increasing for Ukrainian buildings and facilities // Technology Audit and Production Reserves. 2018. Vol. 1, No. 1 (39). P. 48-55. doi:10.15587/2312-8372.2018.85402

2. Yeromin A., Kolosov A. Modeling of energy efficient solutions regarding the heating system and the facade heat insulation in the implementation of thermomodernization // EasternEuropean Journal of Enterprise Technologies. 2018. Vol.1, No. 8 (91). P. 49-57. doi:10.15587/1729-4061.2018.123021

3. DSTU B V.3.2-3:2014. Nastanova z vykonannia termomodernizatsii zhytlovykh budynkiv. Introduced: 01.10.2015. Kyiv: Minrehion Ukrainy, 2014. 70 p.

4. DBN V.2.6-31: 2016. Teplova izoliatsiia budivel'. Approved by the order of the Ministry of Regional Development of Ukraine from 08.07.2016 No. 220. Introduced: 08.10.2016. Kyiv: Minrehion Ukrainy, 2016. $30 \mathrm{p}$.

5. Weglarz A., Gilewski P. G. A Method of Evaluation of Polioptimal Thermomodernization Schemes of Buildings // Procedia Engineering. 2016. Vol. 153. P. 862-865. doi:10.1016/ j.proeng.2016.08.194

6. Kuzniar K., Zajac M. Numerical evaluation of natural vibration frequencies of thermomodernized apartment buildings subjected to mining tremors // Procedia Engineering. 2017. Vol. 199. P. 296-301. doi:10.1016/j.proeng.2017.09.039

7. Assessment of single-family house thermal renovation based on comprehensive on-site diagnostics / Hurnik M. et al. // Energy and Buildings. 2018. Vol. 158. P. 162-171. doi:10.1016/ j.enbuild.2017.09.069

8. Zender-Swiercz E., Piotrowski J. Z. Thermomodernization a building and its impact on the indoor microclimate // Structure and Environment: Architecture, Civil Engineering, Environmental Engineering and Energy. 2013. Vol. 5, No. 3. P. 37-40. 
9. Jaworska-Michalowska M. Ochrona historycznej elewacji w procesie termomodernizacji - wybrane zagadnienia // Czasopismo Techniczne. Budownictwo. 2009. Vol. 106, No. 2-B. P. 151-161.

10. Sadowska B., Sarosiek W. Efficiency of raising low-energy buildings and thermomodernization of existing ones // Biuletyn Wojskowej Akademii Technicznej. 2014. Vol. 63, No. 1. P. 179-191.

11. Rutkowska G., Wojnowski D. Analysis of variants thermomodernization of a dwelling house from a point of view of optimal energetic demands // Inzynieria Ekologiczna. 2014. Vol. 37. P. 162-173.

12. Lundstrom L., Wallin F. Heat demand profiles of energy conservation measures in buildings and their impact on a district heating system // Applied Energy. 2016. Vol. 161. P. 290-299. doi:10.1016/j.apenergy.2015.10.024

13. Bali D., Maljkovi D., Loncar D. Multi-criteria analysis of district heating system operation strategy // Energy Conversion and Management. 2017. Vol. 144. P. 414-428. doi:10.1016/ j.enconman.2017.04.072

14. Kolosov A. E., Virchenko G. A., Kolosova E. P., Virchenko G. I Structural and Technological Design of Ways for Preparing Reactoplastic Composite Fiber Materials Based on Structural Parametric Modeling // Chemical and Petroleum Engineering. 2015. Vol. 51, No. 7-8. P. 493-500. doi:10.1007/s10556-015-0075-3

15. Zender-Swiercz E., Telejko M. Impact of Insulation Building on the Work of Ventilation // Procedia Engineering. 2016 Vol. 161. P. 1731-1737. doi:10.1016/j.proeng.2016.08.766

16. Optimization of Thermal Insulation and Regression Analysis of Fuel Consumption / Lulic H. et al. // Procedia Engineering. 2014. Vol. 69. P. 902-910. doi:10.1016/j.proeng.2014.03.069

17. Image-based thermographic modeling for assessing energy efficiency of buildings fa ades / GonzlezAguilera D. et al. // Energy and Buildings. 2013. Vol. 65. P. 29-36. doi:10.1016/ j.enbuild.2013.05.040

18. Sierra-Perez J., Boschmonart-Rives J., Gabarrell X. Environmental assessment of facadebuilding systems and thermal insulation materials for different climatic conditions // Journal of Cleaner Production. 2016. Vol. 113. P. 102-113. doi:10.1016/ j.jclepro.2015.11.090
19. Sulakatko V., Lill I., Witt E. Methodological Framework to Assess the Significance of External Thermal Insulation Composite System (ETICS) onsite Activities // Energy Procedia 2016. Vol. 96. P. 446-454. doi:10.1016/j.egypro.2016.09.176

20. Elarga H., De Carli M., Zarrella A. A simplified mathematical model for transient simulation of thermal performance and energy assessment for active facades // Energy and Buildings. 2015. Vol. 104. P. 97-107. doi:10.1016/j.enbuild.2015.07.007

21. Vox G., Blanco I., Schettini E. Green facades to control wall surface temperature in buildings // Building and Environment. 2018. Vol. 129. P. 154-166. doi:10.1016/j.buildenv.2017.12.002

22. Cvetkovi D., Boji M. Optimization of thermal insulation of a house heated by using radiant panels // Energy and Buildings. 2014. Vol. 85. P. 329-336. doi:10.1016/j.enbuild.2014.09.043

23. Modeling of facade elements with switchable U-value / Pflug T. et al. // Energy and Buildings. 2018. Vol. 164. P. 1-13. doi:10.1016/ j.enbuild.2017.12.044

24. Investigations on Physicalmechanical Properties of Effective Thermal Insulation Materials from Fibrous Hemp / Kremensas A. et al. // Procedia Engineering. 2017. Vol. 172. P. 586-594. doi:10.1016/j.proeng.2017.02.069

25. Procedure for analysis of ultrasonic cavitator with radiative plate / Kolosov A. E. et al. // Chemical and Petroleum Engineering. 2013. Vol. 48, No. 11-12. P. 662-672. doi:10.1007/ s10556-013-9677-9

26. Yeromin A. V. Systema kompleksnoi termomodernizatsiyi budivel i sporud za Yerominym: Patent No. 115858 C2 UA, MPK F24D3/00, F16L59/00. Appl. No. a201709331. Filed: 25.09.2017. Published: 26.12.2017. Bull. No. 24.

27. Yeromin A. V. Sposib kompleksnoi termomodernizatsiyi budivel i sporud za Yerominym: Patent No. 115760 C2 UA, MPK F24D3/00, F16L59/00. Appl. No. a201709333. Filed: 25.09.2017. Published: 11.11.2017. Bull. No. 23.

Yeromin Andriy, Director, «Complex Engineering Solutions» LLC \& $O$ Online Store HeatRecovery, Kyiv, Ukraine, ORCID: https://orcid.org/ 0000-0001-9547-8047, e-mail: heatrecovery.ua@hotmail.com 